\title{
Sonic hedgehog Regulates Proliferation and Inhibits Differentiation of CNS Precursor Cells
}

\author{
David H. Rowitch, ${ }^{1,2}$ Benoit St.-Jacques, ${ }^{1}$ Scott M. K. Lee, ${ }^{1}$ Jonathon D. Flax, ${ }^{2}$ Evan Y. Snyder, ${ }^{2}$ and \\ Andrew P. McMahon1 \\ ${ }^{1}$ Department of Molecular and Cellular Biology, Harvard University, Cambridge, Massachusetts 02138, and 2Division of \\ Newborn Medicine, Department of Pediatrics, Harvard Medical School, Boston, Massachusetts 02115
}

Activation of the Sonic hedgehog (Shh) signal transduction pathway is essential for normal pattern formation and cellular differentiation in the developing CNS. However, it is also thought to be etiological in primitive neuroectodermal tumors. We adapted GAL4/UAS methodology to ectopically express full-length $S h h$ in the dorsal neural tube of transgenic mouse embryos commencing at $10 \mathrm{~d}$ postcoitum (dpc), beyond the period of primary dorsal-ventral pattern formation and floorplate induction. Expression of Shh was maintained until birth, permitting us to investigate effects of ongoing exposure to Shh on CNS precursors in vivo. Proliferative rates of spinal cord precursors were twice that of wild-type littermates at $12.5 \mathrm{dpc}$. In contrast, at late fetal stages (18.5 dpc), cells that were
Shh-responsive but postmitotic were present in persistent structures reminiscent of the ventricular zone germinal matrix. This tissue remained blocked in an undifferentiated state. These results indicate that cellular competence restricts the proliferative response to Shh in vivo and provide evidence that proliferation and differentiation can be regulated separately in precursor cells of the spinal cord. Thus, Hedgehog signaling may contribute to CNS tumorigenesis by directly enhancing proliferation and preventing neural differentiation in selected precursor cells.

Key words: Sonic hedgehog; tumorigenesis; GAL4; central nervous system; proliferation; differentiation; Wnt-1; medulloblastoma; transgenic mice
Sonic hedgehog (Shh) encodes a secreted glycoprotein that is initially expressed in mesodermal tissues underlying the ventral midline of the murine CNS (Echelard et al., 1993; Marti et al., 1995a). Shh is essential for maintenance of notochord and prechordal mesoderm (Chiang et al., 1996) as well as the induction of floorplate and ventral neuronal populations that form at different positions along the anterior-posterior (AP) axis of the neural tube (Echelard et al., 1993; Roelink et al., 1994, 1995; Marti et al., 1995b; Chiang et al., 1996; Ericson et al., 1997; Jessell and Lumsden, 1997). In addition, there is evidence that Shh signaling may specify oligodendrocyte precursors (Poncet et al., 1996; Pringle et al., 1996). Shh signal transduction is complex (Tabin and McMahon, 1997). The active Shh signal, which is produced by autoprocessing and cholesterol modification (Porter et al., 1996), binds to a receptor complex composed of at least two transmembrane proteins, Patched and Smoothened (Marigo et al., 1996; Stone et al., 1996). Shh binding to Patched is thought to

\footnotetext{
Received June 29, 1999; revised Aug. 5, 1999; accepted Aug. 6, 1999.

We thank Drs. Makoto Ishibashi, Ryoichiro Kageyama, Qiufu Ma, Chuck Stiles, David Fischer, Yann Echelard, Rob Wechsler-Reya, and Matt Scott for comments and stimulating discussions; Yann Echelard for preparation of the Wnt-1-GAL4 transgene; and Dong-In Yuk, Bianca Klumpar, and Wendy Liu for technical assistance. D.H.R. was supported by a Physician Postdoctoral Fellowship from the Howard Hughes Medical Institute and Grant HD01182 from National Institutes of Health. B.S.J. was supported by a postdoctoral fellowship of the Medical Research Council of Canada. These studies were funded by National Institutes of Health Grants NS32691 and HD30249 (A.P.M.) and the Charles H. Hood Foundation and Brain Tumor Society (D.H.R.). D.H.R. is a recipient of a Basil O'Conor Starter Scholar Award from the March of Dimes Foundation.

Correspondence should be addressed to Dr. David H. Rowitch at his present address: Department of Pediatric Oncology, Dana-Farber Cancer Institute, Boston, MA 02115, or to Dr. Andy McMahon, Department of Molecular and Cellular Biology, Harvard University, The Biolabs, 16 Divinity Avenue, Cambridge, MA 02138 .

Dr. St.-Jacques's present address: Ontogeny, Inc., Cambridge, MA 02138. Copyright (C) 1999 Society for Neuroscience $0270-6474 / 99 / 198954-12 \$ 05.00 / 0$
}

relieve Patched-mediated inhibition of Smoothened activity, resulting in the activation of transcriptional targets by members of the Gli family (Ingham et al., 1991; for review, see Ingham, 1998). Although Patched and Gli-1 appear to be general transcriptional targets in vertebrates, other factors are specific to neural precursor cells, including $H N F 3 \beta$ and $N k x$-2.2 (Dale et al., 1997; Ericson et al., 1997).

In contrast to its roles in neural patterning and differentiation, recent studies have implicated the Hedgehog signaling pathway in proliferation and tumorigenesis. Loss-of-function mutations in human PATCHED are associated with activation of the Hedgehog signal transduction pathway and promotion of a neoplastic state characterized by proliferating, undifferentiated cell populations (Hahn et al., 1996; Johnson et al., 1996). Of the children with Gorlin's Syndrome, which is caused by inherited mutations of PATCHED, 3-5\% develop medulloblastoma (Vorechovsky et al., 1997). Inactivating mutations of PATCHED have also been found in sporadically occurring medulloblastoma (Raffel et al., 1997) and basal cell carcinoma, and mice heterozygous for targeted mutations of Patched, in which Shh targets are potentially upregulated, develop cerebellar tumors (Goodrich et al., 1997). Recently, Wechsler-Reya and Scott (1999) provided evidence that Shh is required for granule cell precursor proliferation during cerebellar development, raising the possibility that similar mechanisms are involved during development and tumorigenesis.

Mitogenic effects of Shh have been observed in a number of tissues during development (Fan and Tessier-Lavigne, 1994; Forbes et al., 1996; Huang and Kunes, 1996; Bellusci et al., 1997; Jensen and Wallace, 1997; Oro et al., 1997; Duprez et al., 1998), and misexpression of chicken Shh (Echelard et al., 1993), Gli-1 (Hynes et al., 1997), or a dominant-negative form of protein kinase A $(d n-P K A)$, which activates Shh targets (Epstein et al., 
1996), all resulted in embryonic CNS hyperplasia. The mechanisms underlying such proliferative effects, however, are poorly understood. To gain insight into this process, we have focused on the mitogenic role of Shh in the developing CNS. Our results show that ectopic activation of Hedgehog signal transduction causes enhanced proliferation, but only at embryonic stages. Thus, factors regulating maturation and cellular competence of CNS precursor cells temporally restrict the proliferative response to Shh in vivo.

\section{MATERIALS AND METHODS}

DNA constructs. The plasmid pGaTB and pUAST, encoding full-length GAL4 and a pentamer array of its cognate DNA binding sequence, the upstream activating sequence (UAS), were kindly provided by Drs. A. Brand and N. Perrimon (Harvard Medical School). To generate the transgene pWEXP-GAL4, plasmid pGaTB was digested with HindIII and $F s p$ I to release a DNA fragment encoding $G A L 4$, which was cloned into NruI-digested Wnt-1 expression vector pWEXP-2 (Echelard et al., 1993) (see Fig. 1A). The transgene was purified from vector sequences by digestion with AatII. To generate the reporter transgene pUAS-lac $Z$, the plasmid XB3 (Echelard et al., 1994) was digested with NotI. The pentamer array of UAS sequences from plasmid pUAST were amplified by PCR primers that incorporated NotI and EagI recognition sequences. Once digested, the PCR products were cloned into the XB3 vector to create pUAS-lac $Z$ (see Fig. $1 B$ ). The transgene was purified from vector sequences by digestion with $S a l I$ before pronuclear injection. To generate the mouse Sonic hedgehog misexpression transgene pWEXP3C-Shh, the full-length cDNA was digested from plasmid p8.1 (Echelard et al., 1993) and cloned into the Wnt-1 expression vector pWEXP-3C (Danielian and McMahon, 1996). The transgene was purified from vector sequences by digestion with the restriction endonuclease SalI before microinjection. To generate the transgene pUAS-Shh, a shuttle vector, pUAS-Shuttle, was constructed as follows. The $K p n I$ and $B g l I I$ fragments of plasmid XB3 were replaced with an oligonucleotide containing an XhoI site. This construct was digested with $N o t \mathrm{I}$ and $K p n \mathrm{I}$, and an Not I-KpnI upstream fragment of pUAS-lacZ, comprising five copies of UAS, was added, generating plasmid pUAS-Shuttle. Finally, pUAS-Shuttle was digested with $X h o I$ and $B g l \mathrm{II}$, and an SalI-BglII fragment of pWEXP-3C was cloned into the vector, creating plasmid pUAS-Shh (see Fig. $1 C$ ). The transgene was purified from vector sequences by digestion with SalI and $B g l$ II before microinjection.

DNA sequencing of the constructs listed above was carried out using both ABI dye terminator and dideoxy chain termination methodologies. The orientation and identity of GAL4 and $m S h h$ in constructs pWEXP2GAL4 and pWEXP3C-Shh, respectively, were confirmed by DNA sequencing using oligonucleotide 882 (5'-TAA GAG GCC TAT AAG AGG CGG-3'), which primes $\sim 60$ bp upstream of the Wnt-1 translational initiation site.

Production and genotyping of transgenic mice. Transgenic mice were generated by microinjection of linear DNA fragments, separated from plasmid vector sequences, into pronuclei of B6CBAF1/J $(\mathrm{C} 57 \mathrm{BL} / 6 \mathrm{~J} \times$ $\mathrm{CBA} / \mathrm{J}$ ) zygotes as described (Echelard et al., 1994). The transgenic line Wnt-1/GAL4/cre-11 resulted from coinjection of the transgenes pWEXP2-GAL4 and pWEXP3C-cre (construction and characterization of the pWEXP3C-cre transgene are described elsewhere).

Founder $\left(G_{0}\right)$ transgenic mice were identified by Southern blot of EcoRI-digested genomic DNA and probes for GAL4 (line WEXP2GAL4) or lacZ (lines UAS-lacZ and UAS-Shh). Subsequent genotyping of UAS-lacZ transgenic embryos or mice by PCR was carried out as described in Echelard et al. (1994). Genotyping of WEXP2-GAL4 and UASShh transgenic embryos or mice used an upstream primer from exon 1 untranslated sequence of Wnt-1 (882-TAAGAGGCCATAAGAGGCGG) and a downstream primer from within GAL4 (1061-ATCAGTCTCCACTGAAGC; product size $\sim 600 \mathrm{bp}$ ) or mouse $\mathrm{Shh}$ (930-CTCATAGTGTAGAGACTCCTC; product size $\sim 600 \mathrm{bp}$ ) coding sequences, and the following PCR conditions: $30 \mathrm{sec}, 93^{\circ} \mathrm{C} ; 30 \mathrm{sec}, 55^{\circ} \mathrm{C}, 1 \mathrm{~min}, 72^{\circ} \mathrm{C}$ for 40 cycles; then $5 \min , 72^{\circ} \mathrm{C}$.

Whole-mount histochemistry and skeletal preparation. Analysis of embryos for $\beta$-galactosidase activity was carried out as described by Whiting et al. (1991). For analysis of skeletal elements, 18.5 dpc bigenic fetuses were processed as described (Wallin et al., 1994). Photography of processed embryos or fetuses was performed in $80 \%$ glycerol/PBS on an Olympus SZH10 microscope using Kodak 64T film. Live embryos or fetuses were photographed in PBS using a $35 \mathrm{~mm}$ Nikon camera and daylight film, respectively.

Histological analysis, proliferation studies, and in situ hybridization. For histological analysis, embryos were harvested between 9.5 and $18.5 \mathrm{dpc}$, dissected in PBS, fixed overnight for $24 \mathrm{hr}$ in Bouin's fixative, embedded in paraffin, and sectioned $(6-8 \mu \mathrm{m})$ at forelimb levels of the thoracic spine before staining with hematoxylin-eosin. To analyze proliferation, $50 \mu \mathrm{g} / \mathrm{g}$ of bromodeoxyuridine (BrDU) (Sigma, St. Louis, MO) was injected intraperitoneally into pregnant mothers $3 \mathrm{hr}$ before they were killed at 12.5 and $18.5 \mathrm{dpc}$. Subsequently, four bigenic embryos and wild-type littermates were fixed in paraformaldehyde and sectioned as above. Dividing cells that had incorporated BrDU were identified using monoclonal IgG (Becton Dickinson, San Jose, CA) and immunoperoxidase staining (Vector Laboratories, Burlingame, CA) using diaminobenzidine (Sigma) or FITC-tyramide (DuPont NEN, Wilmington, DE). Terminal deoxynucleotidyl transferase-mediated biotinylated UTP nick end labeling (TUNEL) procedure was performed as described (Gavrieli et al., 1992). Both TdT and biotinylated-16-dUTP were from Boehringer Mannheim (Indianapolis, IN).

In situ hybridization on paraffin sections with radiolabeled antisense RNA probes was performed on either paraformaldehyde or Bouin's fixed tissues according to lab protocols [after Wilkinson (1992); available on request]. Dark-field photomicrographs were collected on a Leitz Orthoplan or Nikon E600 compound microscope using a $35 \mathrm{~mm}$ camera and Fuji Velvia film or a SPOT I digital camera. In situ hybridization on frozen sections of paraformaldehyde-fixed tissues with digoxigeninlabeled antisense probes was performed essentially as described in Ma et al. (1997), and photomicrographs were collected on a Nikon E600 compound microscope using a SPOT I digital camera (Diagnostic Imaging). We thank the following investigators for kindly supplying the in situ hybridization probes used: M. Scott (Ptc-1) (Goodrich et al., 1996); A. Joyner (Gli-1) (Hui et al., 1994); B. Hogan (HNF3ß) (Sasaki and Hogan, 1993); P. Gruss (Pax -6) (Walther and Gruss, 1991) (Pax-3) (Goulding et al., 1993); J. Rubinstein (Nkx-2.2) (Price et al., 1992); R. Johnson (Lmx-1b) (Chen et al., 1998); D. Lachman (Brn-3a) (Theil et al., 1994); L. Roberston (BMP-7) (Lyons et al., 1995); R. Kageyama (HES-1) (Sasai et al., 1992); Genetics Institute, Cambridge, MA (GDF-7) (Storm et al., 1994).

Immunohistochemistry. For immunohistochemistry, embryos were either fresh frozen or fixed between 6 and $24 \mathrm{hr}$ in fresh $4 \%$ paraformaldehyde before freezing and cryostat sectioning $(15 \mu \mathrm{m})$. Antibody against a glutathione $S$-transferase-Hamster L mx fusion protein or Sonic hedgehog was generated in rabbits. Rabbit antisera for Isl-1/2, Nkx-2.2, and Lim-3 were the generous gift of T. Jessell (Columbia University, New York). GalC, O4, and PDGF $\alpha$ R monoclonal antibodies were from Boehringer Mannheim. These and mouse monoclonal antibodies against NeuN (Chemicon, Temecula, CA), TuJ1 (BAbCo, Berkley, CA), Pax-7 (Developmental Studies Hybridoma Bank), and O4 IgM were labeled with anti-rabbit $\mathrm{Cy} 3$ or anti-mouse IgG or IgM-conjugated Cy2 (Jackson ImmunoResearch Labs, West Grove, PA) before visualization by fluorescence microscopy. Photomicrographs were collected on a Nikon E600 compound microscope and SPOT I digital camera (Diagnostic Instruments).

\section{RESULTS \\ Gal4/UAS-targeted gene expression in the Wnt-1 domain}

The Wnt-1 enhancer is well suited for directing gene expression in the roofplate of the spinal cord and was used to overexpress mouse Shh in transgenic mice (D. Rowitch, B. St.-Jacques, and A. McMahon, unpublished observations). However, this resulted in a lethal CNS malformation and precluded maintenance of stable lines. Therefore, on the basis of the work of and Brand and Perrimon (1993) in Drosophila and Ornitz et al. (1991) in mice, we adapted the GAL4/UAS bigenic system for controlled gene expression in the developing murine CNS. Six lines of transgenic mice were generated in which $G A L 4$ was expressed under control of $W n t-1$ regulatory sequences (Wnt-1/GAL4) (Fig. 1A) (see Materials and Methods), as judged by whole-mount in situ hybridization (data not shown). These were subsequently crossed with a reporter line in which expression of lac $Z$ was governed by 
A

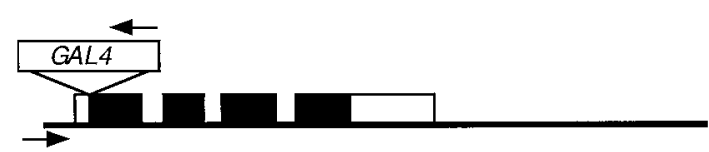

Wnt-1

promoter

Wnt -1

gene

Poly[A] Wnt-1 regulatory sequences
B

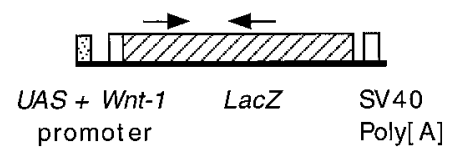

$\square$ Wnt-1 untranslated $\square$ Wht-1 coding घlacZ mRNA tag

Figure 1. Schematic illustration of transgenes WEXP-GAL4, UAS-lacZ, and UAS-Shh used in bigenic system for misexpression in the mouse embryonic CNS. $A$, Plasmid pWEXP-GAL4 comprises full-length $G A L 4$ (Brand and Perrimon, 1993) cloned into the WEXP2 expression vector under control of Wnt-1 regulatory sequences (Echelard et al., 1993). B, The reporter transgenic construct pUAS-lacZ used the Wnt-1 minimal promoter (Echelard et al., 1994) and five copies of the UAS (Brand and Perrimon, 1993). $C$, In plasmid pUAS-Shh, full-length mouse Shh cDNA was cloned into expression vector WEXP3C (Danielian and McMahon, 1996). Wnt-1 regulatory sequences were then replaced by five copies of the UAS. Binding sites for oligonucleotide primers used in genotyping the various transgenic lines are indicated (arrows).

the GAL4 cognate DNA-binding motif, "upstream activating sequence" (Fig. 1B, UAS). When mated to Wnt-1/GAL4 hemizygotes, $25 \%$ of progeny embryos from three of five lines showed $\beta$-galactosidase staining in the $W n t-1$ pattern (Fig. $2 A, B$ ), and one of these lines was selected for further study (designated UASlacZ). All six Wnt-1/GAL4 founders were then screened against the UAS-lacZ line and one of these was selected for further study because of its relatively high levels of activity (designated Wnt-1/ GAL4). Expression of lacZ in double-hemizygous (bigenic) embryos was studied from 8.5 to $18.5 \mathrm{dpc}$. $\beta$-galactosidase staining was first detected at $\sim 9.0 \mathrm{dpc}$ in a region of the ventral midbrain. This represented a delay of $\sim 24 \mathrm{hr}$ in the onset of expression compared with previous observations of lac $Z$ under direct control of Wnt-1 regulatory sequences (Echelard et al., 1994). Expression comprising the full Wnt-1 pattern was seen by $10.5 \mathrm{dpc}$ (Fig. 2, compare $A$ and $B$ ). Maintenance of $\beta$-galactosidase staining was observed at $12.5 \mathrm{dpc}$ (Fig. $2 C$ ) and $18.5 \mathrm{dpc}$, at which point roofplate cells could be clearly identified (Fig. 2D).

\section{Conditional expression of Shh in the developing spinal cord}

To determine whether this bigenic system could also be used to control expression of Shh, the transgenic line UAS-Shh (Fig. 1C) was generated. Of eight founder lines that carried the UAS-Shh transgene, six survived and three transmitted the allele through the germline. One of these promoted expression of Shh in response to GAL4 in the CNS. The UAS-Shh line was viable; hemizygous progeny did not express ectopic $S h h$. The phenotype of bigenic embryos (hereafter termed $S h h$-Tg), comprising ventralization of the midbrain and neural hyperplasia, could first be

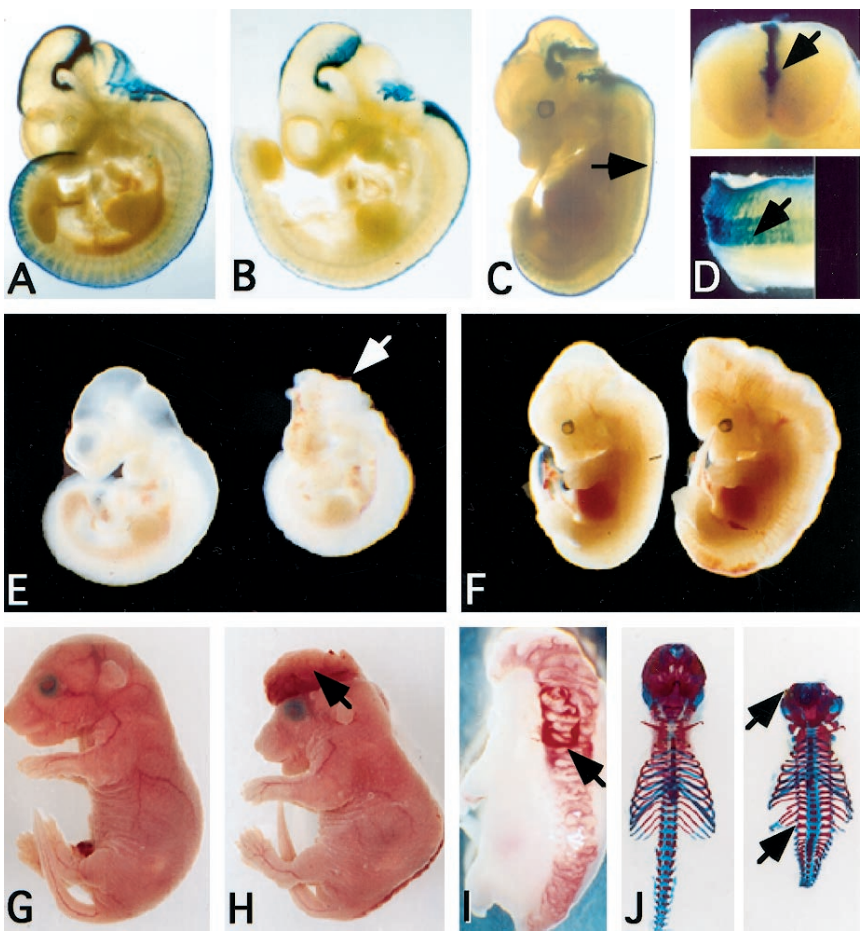

Figure 2. The GAL4/UAS system for gene expression in the developing CNS. $A-D$, Whole-mount histochemical analysis of $\beta$-galactosidase activity in transgenic mouse embryos. $A$, Lateral view showing pattern of lac $Z$ expression under the control of Wnt-1 regulatory sequences (Echelard et al., 1994). B, C, Lateral views of 10.5 and 12.5 dpc bigenic Wnt-1-Gal4 X $U A S$-lacZ embryos showing expression pattern of lacZ (arrow indicates roofplate expression in the spinal cord). $D$, Transverse (top) and bisected (bottom) views of lac $Z$ expression in the rostral spinal cord of bigenic fetus at $18.5 \mathrm{dpc}$. Note staining in roofplate oligodendrocytes that project to the ventricular zone (arrows). E-J, Morphological analysis of wild-type (left) and Wnt-1-GAL4 X UAS-Shh bigenic (right) littermates at $10.5 \mathrm{dpc}(E$, arrow indicates anterior neural tube defect) and $12.5 \mathrm{dpc}(F) . G-J$, Analysis at $18.5 \mathrm{dpc}$. Lateral views of wild-type $(G)$ and bigenic fetuses $(H)$. Note tissue mass protruding from midbrain that covers cerebral hemispheres (arrow). I, Dorsal view of bigenic fetus showing hyperplastic spinal cord that protrudes from the back covered by a thin epithelial membrane. Note prominent vasculature and hemorrhage (arrow). $J$, Dorsal view of skeletal prep of wild-type (left) and bigenic (right) fetuses at $18.5 \mathrm{dpc}$. Note absence of the membranous skull and dorsal neural arches as well as the splayed open configuration of the vertebral bodies (arrows).

distinguished at $9.5 \mathrm{dpc}$ (data not shown) and was followed extensively from 10.5 to $18.5 \mathrm{dpc}$ (Fig. $2 E-J$ ). In contrast to Wht-1-Shh transgenic founder embryos, which display a spectrum of phenotypic severity (Echelard et al., 1993; D. Rowitch, B. St.-Jacques, A. McMahon, unpublished observations), the phenotype of the $S h h$-Tg embryos was highly reproducible. The $S h h$-Tg phenotype was judged as moderate compared with the most severe Wnt-1-Shh founders, which failed to develop craniofacial mesenchyme and died at 14-16 dpc. Gross morphological analysis of $S h h$-Tg fetuses at $18.5 \mathrm{dpc}$ revealed a tissue mass that emanated from the midbrain (Fig. $2 \mathrm{H}$, arrow) and spinal cord tissues with a folded appearance protruding from the back of the animals (Fig. 2I). The membranous skull, the neural arches of the vertebrae, and epiaxial muscle, which normally overlay the brain and spinal cord, were absent (Figs. $2 H-J$ ). In addition, there was pronounced blood supply to the dorsal spinal cord (Fig. 2I). Whether such effects on mesodermal derivatives are caused by Shh itself or are a consequence of neural hyperplasia remains to be determined. 


\section{Increased levels of proliferation in the spinal cord of Shh-Tg mice at embryonic but not fetal stages of development}

Histological analysis of 12.5-18.5 dpc Shh-Tg bigenic embryos demonstrated hyperplasia of the dorsal spinal cord and expansion of the ventricular zone (VZ) (hydromyelia) (Fig. 3, compare $A$ and $E$ with $I$ and $M$ ). In principle, this could result from increased levels of proliferation and/or inhibition of programmed cell death. To assess proliferation in wild-type and $S h h$-Tg embryos, mitotically active cells were labeled with BrDU at 12.5, 14.5, 16.5, and $18.5 \mathrm{dpc}$ and identified in sections taken at the forelimb level (Fig. $3 B, F, J, N$; and data not shown). To quantify levels of proliferation at $12.5 \mathrm{dpc}$, we derived a relative mitotic index (ratio of BrDU-labeled cells in the alar vs basal ventricular zone) in $S h h$-Tg mice (mean $=9.3, S E=1.45 ; n=4)$ and wild-type littermates $($ mean $=3.8, \mathrm{SE}=0.26 ; n=4)$. This indicated that levels of proliferation in $12.5 \mathrm{dpc} S h h$-Tg embryos were approximately twice that of wild-type, reflecting significant $(p<0.001$, Student's $t$ test) elevation in the dorsal compartment where Shh was ectopically expressed. At $14.5 \mathrm{dpc}$, a small population of BrDU-labeled cells were observed in the spinal cord of one of three Shh-Tg embryos, but not in wild-type (data not shown). However, by $18.5 \mathrm{dpc}$ mitotic activity in $S h h$-Tg neural tissue $(n=$ 3) was not above background wild-type levels $(n=3)$ (Fig. 3, compare $J$ and $N$ ).

During spinal cord development, there is evidence for programmed cell death initially in neural crest precursors and the floorplate region at early stages (Homma et al., 1994) and subsequently in ventral motor neuronal populations (Lance-Jones, 1982). To examine programmed cell death in the developing spinal cord, tissue from 12.5, 14.5, and $18.5 \mathrm{dpc}$ wild-type and transgenic mice was analyzed by the TUNEL procedure. No differences were observed between wild-type and $S h h$-Tg samples even as late as $18.5 \mathrm{dpc}$ (data not shown). We conclude from these studies that hyperplasia of the dorsal spinal cord in $S h h$-Tg mice is most likely a result of proliferation per se, rather than inhibition of apoptotic cell death. Interestingly, Shh was capable of promoting proliferation at $12.5 \mathrm{dpc}$, when precursors are normally competent to divide, but not at $18.5 \mathrm{dpc}$, when neurogenesis is complete. Thus a "clock" that normally temporally restricts the period of neural precursor proliferation in wild-type embryos also appeared to be operative in $S h h$-Tg mice.

Given these dramatic differences in cellular response, it was important to establish that the Hedgehog signal transduction pathway was active at both of these time points. Transcriptional targets of Shh include the transmembrane receptor Patched-1 and the zinc finger transcription factor Gli-1. Upregulation of Ptc-1 and Gli-1 was observed at both 12.5 and $18.5 \mathrm{dpc}$ (Fig. $3 G, H, O, P)$, confirming activation of Shh signal transduction. Additionally, high levels of Shh expression (Fig. 3R) and protein production (Fig. $3 S$ ) were maintained at 18.5 dpc. Thus, activation of Shh signal transduction was not able to promote proliferation in the spinal cord at late fetal stages.

\section{Proliferative effects of Shh in the absence of floorplate}

Induction of floorplate has been observed when notochord was ectopically grafted in the chick neural tube (Placzek et al., 1993) or when naive neural plate tissues were treated with the N-terminal fragment of Shh (N-Shh) (Marti et al., 1995b; Roelink et al., 1995), but such effects were limited to early developmental stages (Placzek et al., 1993; Ericson et al., 1996). In addition, proliferative effects of notochord and floorplate have been ob- served previously (van Straaten et al., 1989; Placzek et al., 1993). One possibility was that induction of floorplate in Shh-Tg mice could lead to proliferation by factors other than Shh. However, ectopic expression of $H N F 3 \beta$ in floorplate structures was not observed in the spinal cord at either 10.5 or 18.5 dpc (Fig. $3 T$ ), in keeping with previous observations (Echelard et al., 1993; Epstein et al., 1996). These data indicate that $S h h$ expression in the spinal cord of Shh-Tg mice occurs beyond the phase of competence to induce floorplate (Ericson et al., 1996). At $10.5 \mathrm{dpc}$, there was broad expression of $H N F 3 \beta$ throughout the midbrain, indicating ventralization (Echelard et al., 1993) (data not shown). This may account in part for a failure in anterior neural tube closure (Fig. $2 E$ ). Because neural tube defects can have secondary effects on proliferation, patterning, and tissue survival, we focused our studies at the forelimb and posterior cervical spinal cord levels.

\section{Ectopic Shh expression confers mixed dorsal-ventral character to the embryonic spinal cord}

Sonic hedgehog is normally expressed in organizing structures at the ventral midline from early stages of neural development. Given that $S h h$ expression in $S h h$-Tg mice occurs beyond the phase of competence to form floorplate, we investigated how dorsal-ventral organization was subsequently affected in 12.514.5 dpc embryos. Secreted factors, such as bone morphogenetic proteins (BMPs), from the non-neural ectoderm and roofplate, are thought to act on neural plate precursors to establish dorsal identity (Liem et al., 1997; Lee et al., 1998). Dorsal neural precursors can be recognized by expression of the molecular markers Pax-3 and Pax-7 at appropriate stages in wild-type mice at $12.5 \mathrm{dpc}$ (Fig. 4A) (Tanabe and Jessell, 1996). In Shh-Tg embryos, Pax-3 expression was maintained in the alar plate, indicating that dorsal cell types that were established before ectopic Shh expression were maintained despite ectopic Shh activity (Fig. 4B). To investigate whether precursor cells with ventral character were induced, we tested expression of the marker $N k x-2.2$. $N x k-2.2$ was detected exclusively in the ventral neural tube of $12.5 \mathrm{dpc}$ wild-type embryos (Fig. 4C) but was ectopically induced in the dorsal region of $S h h-T g$ embryos (Fig. $4 D$ ). Thus, populations of neural precursor cells with dorsal and ventral character occupied a similar domain in the alar plate of the spinal cord in $12.5 \mathrm{dpc} S h$-Tg embryos. Pax -6 is expressed predominantly at $12.5 \mathrm{dpc}$ in the ventral ventricular zone of the neural tube as well as in postmitotic ventral neurons (Fig. 4E). Expression of Pax -6 can be repressed by Shh in neural plate explants in culture (Ericson et al., 1997). However, we observed dramatic upregulation of Pax-6 in the alar plate of $S h$-Tg mice (Fig. $4 F$ ), consistent with the findings of Monsoro-Burq et al. (1995). Pax -6 expression appeared to be a sensitive indicator of immature ventricular zone precursors exposed to ectopic Shh.

It was possible that hyperproliferating precursor cells in $\mathrm{Sh}$ - Tg mice could be giving rise to cells with dorsal, ventral, or mixed character. BMPs function as determinants of dorsal character in the spinal cord and are expressed in the roofplate and adjacent non-neural ectoderm of the embryonic neural tube (Liem et al., 1997; Lee et al., 1998) as well as the meninges. Our results indicated that $B M P-7$ expression in the meninges surrounding the spinal cord was similar in wild-type and transgenic embryos (Fig. $4 G, H)$. Analysis of $W n t-3 a$ expression confirmed that a roofplate population was maintained and expanded in $S h h$-Tg mice (Fig. $4 I, J)$. Moreover, dorsal neural tissues continued to express GDF-7 (Fig. 4K,L) (Lee et al., 1998). Thus, BMP and Wnt gene family members normally expressed in the roofplate were main- 


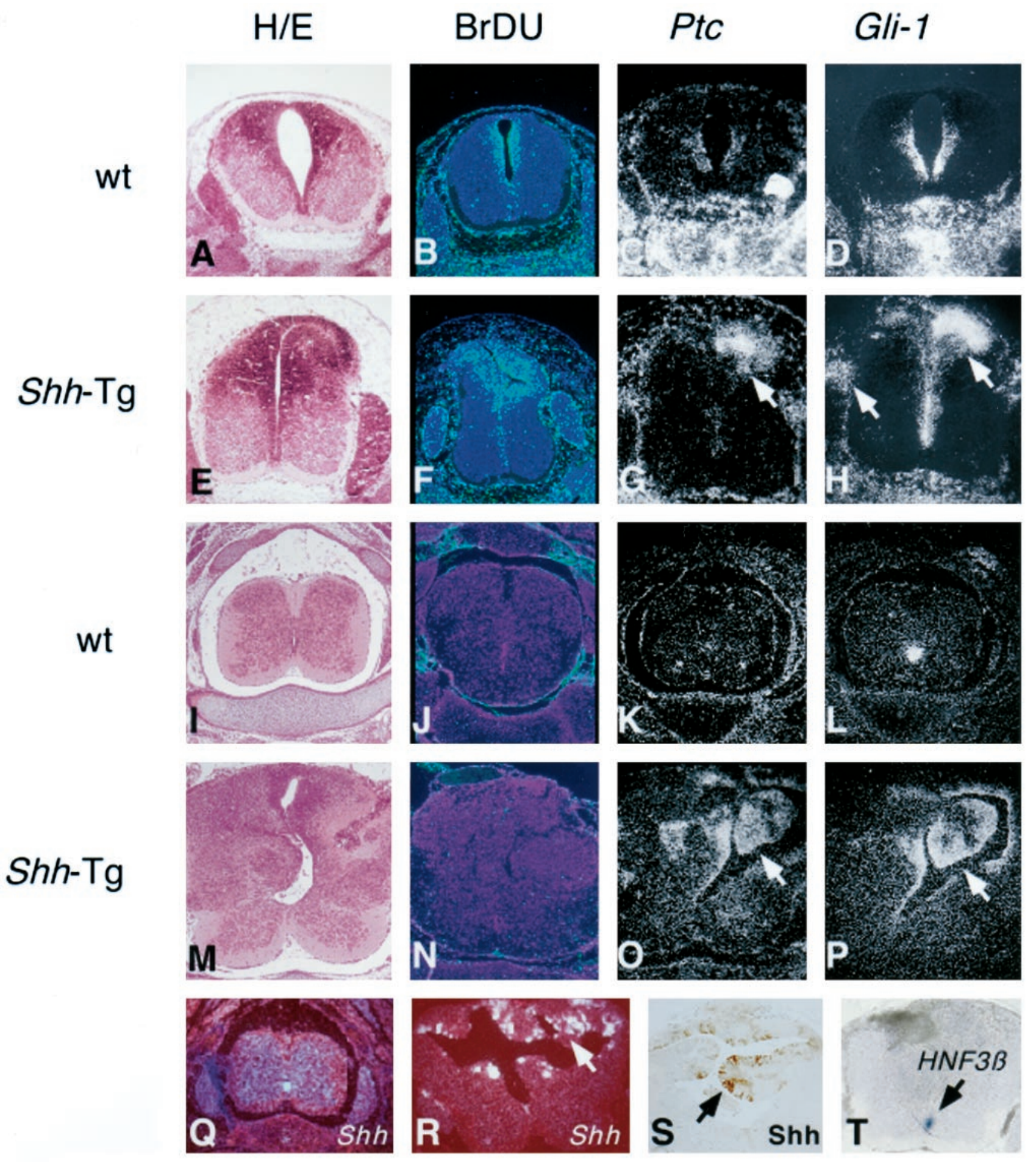

Figure 3. Analysis of spinal cord morphology, rates of precursor cell proliferation, and state of Shh signal transduction in wild-type $(A-D, I-L, Q)$ and $S h h-\operatorname{Tg}(E-H, M-P, R-T)$ spinal cord at 12.5 and 18.5 dpc. $A, E, I, M$, Histological analysis of transverse sections taken at the forelimb level. $E, M$, Note hyperplasia and expansion of dorsal regions of the spinal cord of $S h h$-Tg embryos. $M$, At $18.5 \mathrm{dpc}$ the central canal of the spinal cord is grossly enlarged and distended (hydromyelia). $B, F, J, N$, BrDU incorporation in dividing cells at $(B, F) 12.5 \mathrm{dpc}$ and $(J, N) 18.5 \mathrm{dpc}$. Note that proliferative rates are low at $18.5 \mathrm{dpc}$ in both wild-type and mutant specimens. RNA in situ hybridization showing expression of Ptc-1 at $12.5 \mathrm{dpc}(C, G)$ and $18.5 \mathrm{dpc}(K, O)$. Note ectopic dorsal expression in $S h h$-Tg tissues $(G, O$, arrows $)$. Expression of $G l i-1$ at $12.5 \mathrm{dpc}(D, H)$ and $18.5 \mathrm{dpc}(L, P)$. Note ectopic dorsal expression in $S h h$-Tg spinal cord $(H, P)$ and dorsal root ganglion $(H$, left arrow). $Q-T$, Tissue from 18.5 dpc fetuses. $Q, R$, Wild-type and $S h h$-Tg cervical spinal cord tissues showing expression of Shh. S, Distribution of Shh protein demonstrated by immunostaining with anti-Shh serum (Marti et al., 1995a). T, In situ hybridization showing expression of $H N F 3 \beta$. Note that expression is confined to the floorplate region (arrow). 

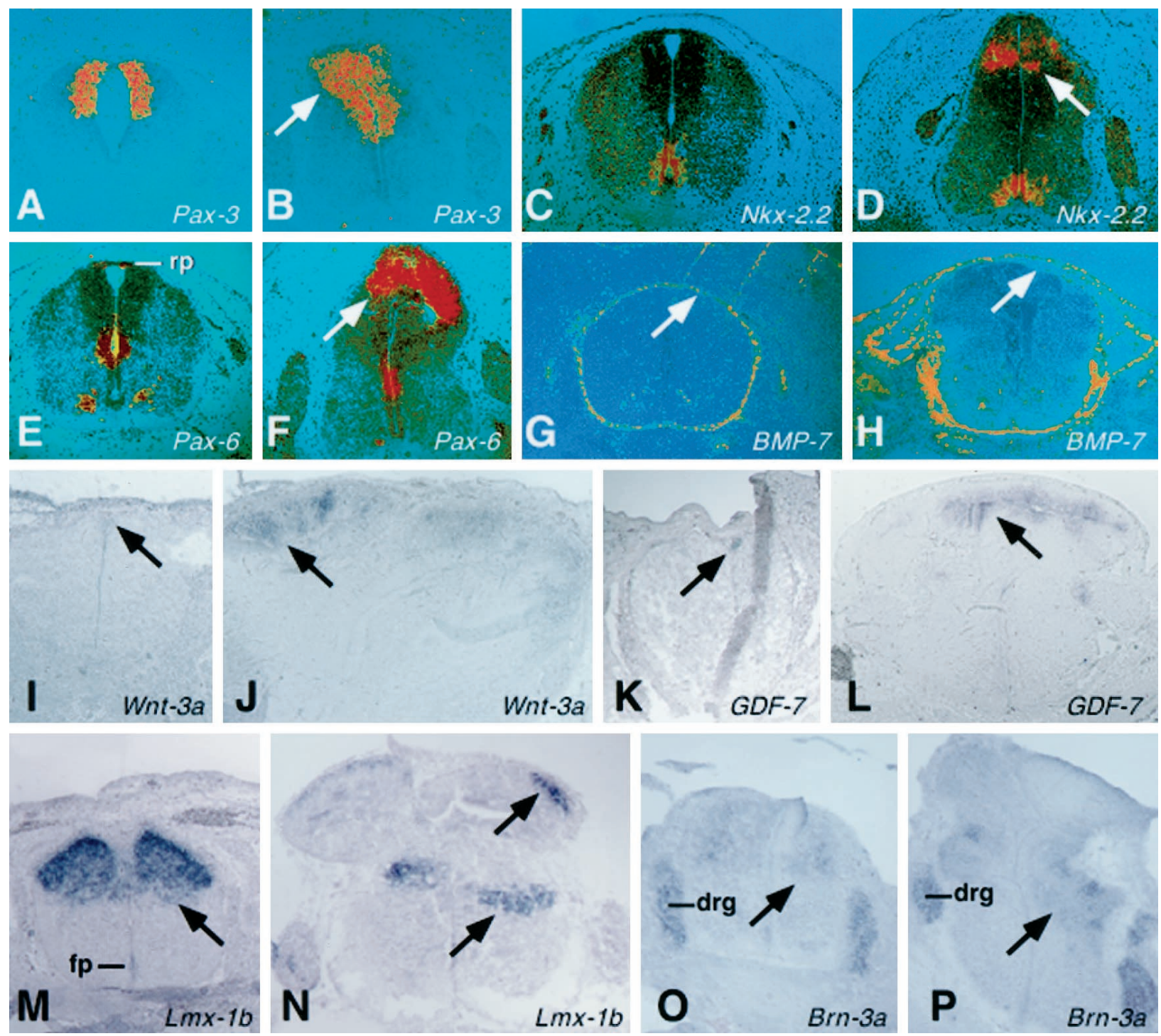

Wnt-3a

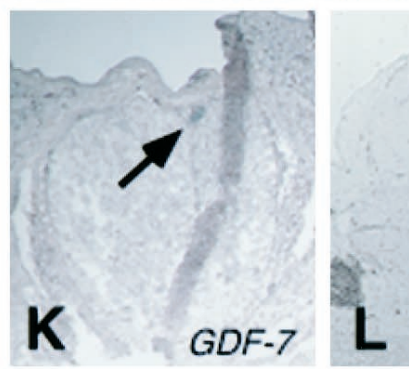

GDF-7

Figure 4. Analysis of dorsal-ventral organization in the spinal cord of 12.5-14.5 dpc Shh-Tg embryos. In situ hybridization was performed on $12.5 \mathrm{dpc}$ $(A-F, O, P)$ and $14.5 \mathrm{dpc}(G-N)$ spinal cord from wild-type $(A, C, E, G, I, K, M, O)$ and $S h h$-Tg $(B, D, F, H, J, L, N, P)$ embryos. Expression of $P a x-3$ $(A, B)$ is maintained in $S h h$-Tg tissue (arrow). $C, D, N k x-2.2$ is expressed in ventral ventricular zone (C, arrow) and ectopically in $S h h$-Tg tissue $(D$, arrow). $E, F$, Expression of Pax-6 normally occurs in the roofplate $(r p)$ but is strongly upregulated in the $S h h$-Tg tissue $(F$, arrow). $G, H, B M P-7$ expression in the meninges was unaffected in Shh-Tg mice (arrows). I, J, Maintenance and expansion of roofplate cells indicated by expression of Wnt-3a in Shh-Tg tissue. $K, L$, Expression of $G D F-7$ was weakly detected in wild-type mice and strongly maintained in dorsal tissues of $S h h$-Tg mice. $M, N$, Pattern of $L m x-1 b$ expression. Note large dorsal region in which $L m x-1 b$ expression is interrupted. $f p$, Floorplate. $O, P$, Expression of the postmitotic neuronal marker Brn-3a in dorsal spinal cord (arrows) and dorsal root ganglion ( $d r g)$.

tained in Shh-Tg mice. To further characterize development of dorsal populations, we tested expression of $L m x-1 b$ (Chen et al., 1998), which is expressed in cells throughout a large region of the dorsal spinal cord and to a lesser extent in the floorplate (Fig. $4 M$ ). Interestingly, we observed that the $L m x-1 b$ domain was interrupted in $S h h$-Tg mice (Fig. $4 N$ ). Taken together, these results suggested that although Shh did not suppress the commitment to early dorsal fates, hyperplastic tissue that was generated later lacked certain dorsal characteristics. Further evidence for this sequence was provided by examination of Brn-3a expression, a marker of postmitotic dorsal neurons that can be suppressed when a source of ectopic Shh is grafted into the early chick neural tube (Fedtsova and Turner, 1997). Maintenance of Brn-3a expression was observed in $\mathrm{Sh}$-Tg embryos at $12.5 \mathrm{dpc}$, indicating that onset of Shh exposure likely followed that of early specification of Brn-3a + neurons (Fig. 4, compare $O$ and $P$ ). In summary, our results suggested that early dorsal patterning of the neural tube was unaffected in $S h h$-Tg mice, consistent with the delayed onset of Shh activation. However, later populations of precursors exposed to the ectopic Shh signal gave rise to cells expressing ventral markers. Ultimately, the resulting structure comprised a hyperplastic and disorganized dorsal extension superimposed on a spinal cord in which the dorsal-ventral pattern was largely intact.

\section{Cells of the expanded ventricular zone in Shh-Tg mice are blocked in an undifferentiated state}

We next investigated the ultimate cell fates acquired in the hyperplastic dorsal spinal cord tissue of Shh-Tg mice. Because 

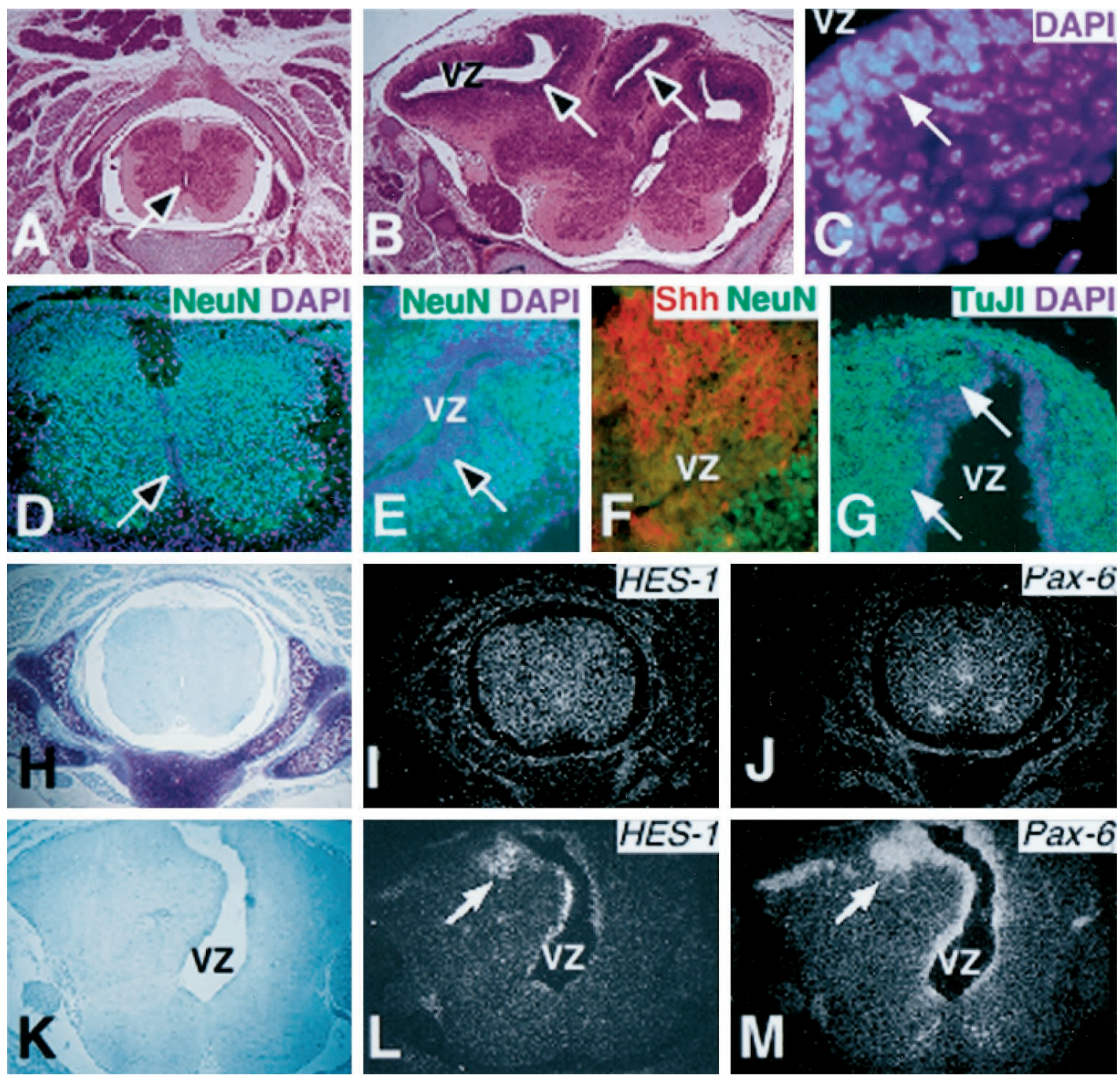

Figure 5. Absence of differentiation in cells lining the enlarged ventricular zone in $18.5 \mathrm{dpc} S h h-\mathrm{Tg}$ mice. $A, B$, Histological analysis of wild-type $(A)$ and $S h h-\operatorname{Tg}(B)$ spinal cord at the forelimb level with hematoxylin-eosin. Note that the ventricular zone $(V Z)$ is massively enlarged in $S h h$-Tg mice (arrows). In addition, the tissue surrounding the $\mathrm{VZ}$ is hyperplastic. $C$, Cells lining the $\mathrm{VZ}$ have a pseudostratified columnar appearance as revealed by the nuclear stain $D A P I$. $D-G$, Immunocytochemistry of VZ region in wild-type $(D)$ and $S h h$-Tg $(E-G)$ tissue. $D, E$, The mature neuronal marker NeuN ( green) counterstained with DAPI (blue). Compare the sizes of ventricular zone (arrows) and the absence of NeuN labeling. F, Shh expression (red) was confined to VZ cells and did not overlap NeuN+ cells ( green) in the surrounding hyperplastic tissue (arrows). $G$, Labeling with $\beta$-tubulin III (TuJ1, green) is excluded from the VZ (arrows). $H-M$, In situ hybridization of wild-type $(H-J)$ and $S h h-\mathrm{Tg}(K-M)$ fetuses. $H$, $K$, Bright-field images are shown for orientation. $I, L$, Expression of HES-1 was upregulated in $S h h$-Tg (arrow) in cells lining the VZ. J, M, Pax-6 was maintained in a similar pattern of expression (arrow).

Wnt-1-GAL4 expression persists throughout the antenatal period, it is possible to characterize effects of ongoing ectopic Shh pathway activation in tissue until late fetal stages. A landmark structure in the wild-type spinal cord is the ependymal cell-lined central canal (Fig. 5A,D). A striking finding in Shh-Tg mice is that the central canal is massively enlarged and often has a folded appearance in section (Fig. $5 B$ ). Of particular interest was a cell-dense, pseudostratified periventricular layer that was revealed by the nuclear stain DAPI (Fig. 5C,E). This was reminiscent of the periventricular neuroepithelial germinal zone, a structure normally found only at earlier time points in spinal cord development, which disappears as neural precursors differentiate and emigrate from this region. Consistent with this interpretation, we never observed labeling with mature (NeuN) or immature $(\mathrm{TuJ} 1)$ neuronal markers within the persistent periventricular zones (Fig. $5 E, G$ ) or immunolabeling with the astrocyte marker GFAP or the oligodendrocyte markers GalC or O4 (data not shown). Antibodies against the N-terminal fragment of Shh (Marti et al., 1995b) revealed that Shh proteins were produced exclusively within the enlarged VZ (Figs. $3 R, S, 5 F$ ), a region of dramatic Ptc- 1 and Gli-1 upregulation in Shh-Tg mice (Fig. 3O,P). Further confirmation of the immature character of the VZ cells was provided by analysis of HES-1 (Sasai et al., 1992) and Pax-6 expression. Overexpression of HES-1 in the rodent neural tube causes delay or inhibition of differentiation (Ishibashi et al., 1994), whereas HES-1 loss of function results in premature differentiation of neural plate precursor cells (Ishibashi et al., 1995). We observed that HES-1 expression was upregulated in the ventricular zone of $S h h$-Tg mice (Fig. 5L). Our finding of Pax -6 expression in the same region (Fig. $5 M$ ) further suggests that VZ cells at $18.5 \mathrm{dpc}$ share similar properties with ventricular zone precursor cells during the period of neurogenesis (Tanabe and Jessell, 1996). Thus, markers normally associated with precursor populations and dividing cells present during embryogenesis revealed 

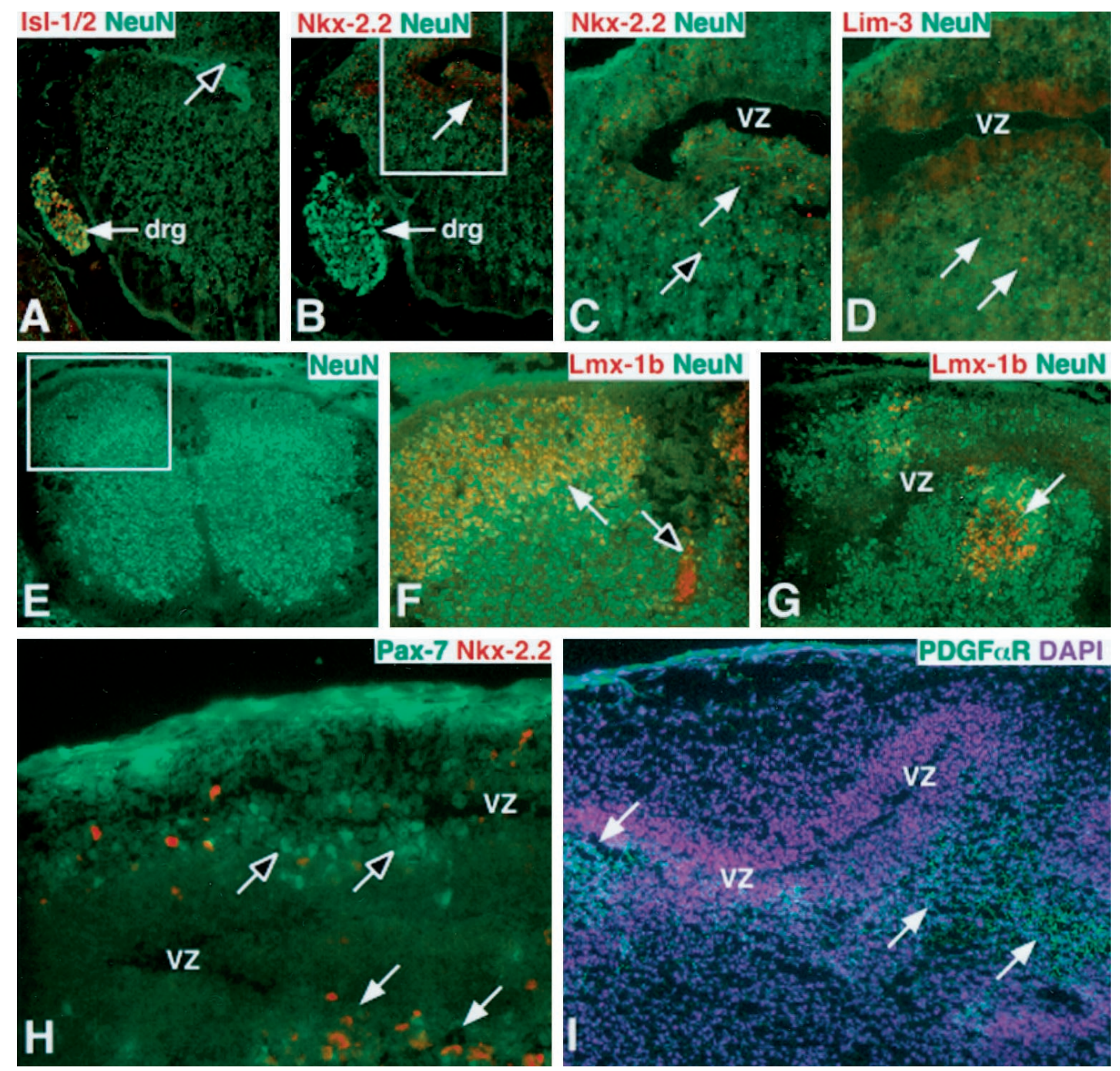

Figure 6. Analysis of neuronal and oligodendroglial cell fate in the dorsal spinal cord of $S h h$-Tg mice. Immunocytochemistry of wild-type (E, $F$ ) and Shh-Tg $(A-D, G-I) 18.5$ dpc fetuses. $A$, Isl-1/2 (red) labeled cells of the dorsal root ganglion (drg, white arrow) and a few cells in the dorsal spinal cord in one of five specimens analyzed (hollow arrow). Note absence of counterstain with the mature neuronal marker NeuN (green) in dorsal cells. B, Numerous Nkx-2.2+ cells were detected in regions surrounding the VZ (diagonal arrow) but not the drg. $C$, The area boxed in $B$ at higher power. Not all Nkx-2.2+ cells (e.g., solid arrow) counterstained with NeuN (hollow arrow), which suggests relative immaturity. $D$, Region adjacent to VZ analyzed with Lim-3 demonstrating numerous positive cells (red, arrows). E, F, Analysis of Lmx-1b populations (red) in the substantia gelatinosa region (boxed in $E$, and $F$ ) and roofplate ( $F$, hollow arrow) counterstained with NeuN (green). Contrast the organization of Lmx-1b+cells in the wild-type ( $G$ ) with those of Shh-Tg spinal cord tissue. H, Labeling of cells with the dorsal marker Pax-7 (green, hollow arrows) compared with the ventral neuronal marker Nkx-2.2 (red, solid arrows). Cells expressing both markers were not detected. I, Oligodendrocyte precursors are induced in regions adjacent to the Shh-expressing VZ, as indicated by the marker PDGF $\alpha$ R (green). Counterstain with DAPI is blue.

ectopic induction and striking persistence into late fetal stages in the CNS of Shh-Tg mice.

\section{Induction of neuronal and oligodendroglial lineages in hyperplastic tissue adjacent to Shh-producing ventricular zone cells}

The preceding results demonstrated that regions of highest Hedgehog pathway activation formed large ventricular zone structures comprising cells maintained in an undifferentiated state. In contrast, neuronal differentiation clearly occurred in the hyperplastic tissue adjacent to the persistent VZ structures in Shh-Tg mice, as demonstrated by immunolabeling with the mature neuronal marker Neu-N (Fig. $5 E$ ). Several lines of evidence indicate that Shh is necessary and sufficient for ventral neuron (in particular motor neuron) and oligodendrocyte induction (Marti et al., 1995b; Roelink et al., 1995; Chiang et al., 1996; Ericson et al., 1996; Poncet et al., 1996; Pringle et al., 1996; Orentas et al., 1999). Thus, we determined whether ventral motor neurons or oligodendrocytes were induced in $S h h$-Tg mice.

We initially tested expression of molecular markers associated with postmitotic ventral neuronal populations including c-ret, Isl-1, and En-1. Although ventrally located motor and interneuronal populations were clearly identified, ectopic expression of these markers was not observed (data not shown). Some dorsally located neurons normally express Isl-1 (Liem et al., 1997). However, additional numbers of Isl-1/2 neurons were only observed in 1 out of $5 \mathrm{Sh}$-Tg animals analyzed (Fig. $6 A$ ). One possibility was that the dose of Shh may have been either too low or too high for efficient Isl-1 motor neuron induction, because concentration dependence of motor neuron induction has been demonstrated in chick neural explant culture (Roelink et al., 1995; Ericson et al., 
1997). We therefore analyzed tissue for the presence of Lim-3 and Nxk-2.2 neurons. These markers indicate cell populations lying immediately dorsal and ventral to the region normally giving rise to motor neurons in the ventricular zone (Tanabe et al., 1998; Briscoe et al., 1999), and they can be induced with lower and higher concentrations of N-Shh, respectively (Ericson et al., 1997). As shown (Fig. 6B-D), we readily detected ectopic induction of $\mathrm{Nkx}-2.2+$ and Lim-3+ cells in regions adjacent to the enlarged ventricular zone. Thus, it is unlikely that the failure to form Isl-1+ neurons is related to the dosage of Shh in Shh-Tg mice. A second possibility was that Shh actually inhibited the differentiation of Isl-1 motor neurons, as suggested from in vitro studies (Kalyani et al., 1998). We therefore analyzed Shh-Tg dorsal spinal cord cells in dispersed explant cultures for generation of Isl-1 neurons. Although numerous Lim-3+ and Nkx-2.2+ neurons were detected, we failed to detect Isl-1+ neurons after 5-7 d in culture (data not shown). Thus, the most likely explanation for the lack of Isl-1 motor neuron induction is that temporal restrictions on competence are exceeded by the time of Shh production in $\mathrm{Sh} h$-Tg mice.

We next investigated the dorsal nature of tissue in $S h h$-Tg mice at $18.5 \mathrm{dpc}$ with the marker Lmx-1b. Although $L m x-1 b$ is expressed in the floorplate and dorsal spinal cord at embryonic stages (Fig. 4J), Lmx-1b antisera only labels dorsal cells at both embryonic and fetal stages (data not shown). In the wild-type fetus, Lmx-1b is detected broadly in neurons of the substantia gelatinosa (orange/yellow) and the roofplate (red) (Fig. 6F). In contrast, the distribution of Lmx-1b cells is disorganized in Shh-Tg mice (Fig. 6G). We conclude from this that Lmx-1b cells persist in the dorsal spinal cord and are interspersed with cells of ventral character (e.g., Nkx-2.2+ neurons). These results do not rule out the possibility that cells with mixed dorsal-ventral character were elaborated in $S h h$ - Tg mice. To assess this, we immunolabeled dorsal spinal cord tissue with antibodies against the ventral neuronal marker Nkx-2.2 and the dorsally restricted marker Pax-7 (Tanabe and Jessell, 1996). As shown (Fig. 6H), we did not detect cells that expressed both markers.

Oligodendrocyte precursors arise from a similar region of the neural tube that gives rise to motor neurons (Sun et al., 1998) and can be induced at an identical concentration of N-Shh in neural explant culture (Pringle et al., 1996). To determine whether oligodendrocyte precursors were induced in $S h h$-Tg mice, we performed immunolabeling with PDGF $\alpha \mathrm{R}$ (Pringle and Richardson, 1993). As shown in Figure 6I, we observed numerous PDGF $\alpha \mathrm{R}+$ cells in regions adjacent to the VZ, the source of ectopic Shh. Induction of $\mathrm{O} 4+$ cells was observed in a similar distribution; however, GalC + oligodendrocytes were only detected in the axons of the dorsal funiculus (data not shown). These results confirmed that the oligodendrocyte lineage was induced in the hyperplastic tissue surrounding the $\mathrm{VZ}$ in Shh-Tg mice.

\section{DISCUSSION}

Ectopic Hedgehog signaling has been implicated in the etiology of CNS tumors (Hahn et al., 1996; Johnson et al., 1996); however, mechanisms underlying Hedgehog-mediated tumorigenesis are poorly understood. We have used a $G A L 4 / U A S$ bigenic system (Ornitz et al., 1991; Brand and Perrimon, 1993; Wang et al., 1997), which allows for the production of stable transgenic lines to produce large numbers of embryos that express a lethal transgene, to explore the effects of maintaining ectopic Shh activity in the dorsal neural tube as a model of deregulated Hedgehog signaling in the developing CNS. Analysis of bigenic embryos revealed dramatic neural hyperplasia and enhanced proliferative levels at $12.5 \mathrm{dpc}$. However, at $18.5 \mathrm{dpc}$, neural tissue was postmitotic, despite the fact that cells were exposed to Shh and still responsive, as demonstrated by upregulation of two general transcriptional targets, Ptc-1 and Gli-1.

\section{Shh proliferative effects in the developing spinal cord}

Several studies using primary CNS precursor cell cultures have demonstrated proliferative effects of the biologically active N-Shh protein after treatment for 36-48 hr (Jensen and Wallace, 1997; Kalyani et al., 1998). Whether Shh functions as a direct mitogen in vitro, however, has not been established (Jensen and Wallace, 1997). In a transgenic gain-of-function model, resolving whether proliferative effects of Shh are direct is difficult, because Shh could lead to induction of other mitogens (e.g., Wnts/BMPs) (Dickinson et al., 1994). Unfortunately, it is not feasible to remove all Wnt/BMP function from this model to determine whether the phenotype also depends on these activities. However, the expansion and patterning abnormalities clearly require Shh, and the induction of ventral cell types (e.g., Nkx-2.2) is most consistent with direct Shh signaling. Moreover, our observations are entirely consistent with a number of in vitro studies of Shh proliferative effects on CNS precursors (Jensen and Wallace, 1997; Kalyani et al., 1998; Wechsler-Reya and Scott, 1999) and the finding that Patched mutations in mice result in highly proliferative cerebellar tumors (Goodrich et al., 1997). An obvious question remains whether Shh has a role in regulating proliferation during normal spinal cord development, as has been reported recently for cerebellar granule cells (Wechsler-Reya and Scott, 1999).

Our findings from analysis of proliferation in vivo indicate that CNS precursors are competent to proliferate in response to activation of the Shh signal transduction pathway only at selected periods during embryogenesis. Overexpression of the Hedgehog transcriptional target Gli-1 resulted in increased levels of proliferation in the developing mouse brain (Hynes et al., 1997) and Xenopus ectoderm (Dahmane et al., 1997); moreover, GLI upregulation has been associated with brain tumors and basal cell carcinoma in humans (Dahmane et al., 1997). We have used Gli-1 and Patched -1 to confirm activation of Shh signal transduction at both 12.5 and $18.5 \mathrm{dpc}$ in the CNS of Shh-Tg mice. However, given that levels of proliferation were significantly elevated only at embryonic stages, it is clear that Gli-1 overexpression is itself insufficient for proliferation in neural tissues at $18.5 \mathrm{dpc}$. Rather, it is possible that Gli-1 acts in concert with other determinants of cell cycle regulation to effect a proliferative state, as has been suggested previously (Ruppert et al., 1991). In preliminary analysis, we have observed that explant cultures of dorsal spinal cord tissue from $17.5 \mathrm{dpc} S h$-Tg fetuses resume proliferation after $3 \mathrm{~d}$ in serum-free media. Further work will be required to determine whether dispersal of such tissue liberates environmental (i.e., secreted or matrix-associated) signals that antagonize Shh proliferative effects.

\section{Shh signaling prevents differentiation of neural precursors}

Although our results are consistent with a mitogenic role for Shh in the neural tube, a second possibility is that proliferative effects are an indirect consequence of preventing or delaying differentiation of neural precursors. A ventricular zone germinal matrixlike structure comprising primitive undifferentiated yet nondivid- 
ing cells persisted in the dorsal spinal cord of Shh-Tg mice. At $18.5 \mathrm{dpc}$, cells in these regions expressed markers indicative of mitotically active neural precursors such as Pax-6, HES-1, and $D b x-1$. Whether these cells represent true multipotential precursors or are restricted in their potential to form neural cell types is under study.

Our results suggest possible mechanisms downstream of Shh signaling that could function to inhibit neuronal differentiation. In $S h h$-Tg mice, superimposition of endogenous dorsalizing signals (e.g., GDF-7, BMP-7) with Shh resulted in a broad overlap of the ventral marker $N k x-2.2$ with dorsally expressed Pax-3 at $12.5 \mathrm{dpc}$. We evaluated whether the mixed signals in the dorsal compartment might have prevented differentiation of cells along a coherent pathway. However, we did not detect any cells coexpressing the ventral and dorsal markers Nkx-2.2 and Pax-7, making such a mechanism unlikely. Another possibility is that persistent expression of Pax 6 or other factors associated with neural precursors could institute a block to terminal differentiation. Upregulation of HES-1, in particular, suggests that such a mechanism may be functioning in $S h h$-Tg mice. Interestingly, Kalyani et al. (1998) and Wechsler-Reya and Scott (1999) recently reported that Shh can directly inhibit differentiation of neuronally restricted precursor cells in vitro.

\section{Absence of ectopic floorplate in Shh-Tg mice}

We determined that Shh effects on proliferation and differentiation were not mediated by ectopic floorplate. Conversion of the entire spinal cord to floorplate has been observed in Patcheddeficient mice (Goodrich et al., 1997), establishing the competence of the lateral (future dorsal) neural plate to respond to Shh signaling at early stages. The kinetics of Wnt-1/GAL4-XUAS-Shh expression initiates $S h h$ expression at $\sim 9.5-10 \mathrm{dpc}$ in the spinal cord, when dorsalizing signals (e.g., from roofplate and nonneural ectoderm) (Liem et al., 1997; Lee et al., 1998) have already commenced. In the face of non-naive tissues, Shh is inadequate to convert the dorsal spinal cord to floorplate (Placzek et al., 1993; Ericson et al., 1996). Indeed, maintenance of Wnt-3a and GDF-7 expression in $S h h$-Tg mice indicates that important dorsal organizing properties of the roofplate cannot be suppressed by Shh beyond an early naive phase.

\section{Developmental neuropathology of CNS tumors}

Given that CNS tumors can arise in tissues well after primary patterning events have taken place, it is relevant to consider the temporal role of the Hedgehog signaling pathway. Our results indicate that activation of Hedgehog signaling at $10.5 \mathrm{dpc}$ in neural tissue that has already acquired dorsal character can result in mixed and complex morphology. The persistent and massively enlarged ventricular zone in $S h h$-Tg mice was surrounded by hyperplastic and largely nestin-positive tissues comprising both dorsal and ventral neuronal cell types. For example, we observed patches of cells expressing the dorsal marker Lmx-1b adjacent to tissue containing ectopic Lim-3+ and Nkx-2.2+ neurons. Although Shh is capable of ventral motor neuron induction at early developmental stages, we did not detect induction of Isl-1+ motor neurons, most likely because $\mathrm{Shh}$ is produced at $10.5 \mathrm{dpc}$ in $S h h$-Tg mice, beyond the period when neural tube is capable of forming ectopic floorplate or motor neurons. In addition, foci of both astrocytes and oligodendrocyte were also observed.

Whether these findings are relevant as an indication of effects of active Hedgehog signal transduction contributing to a tumorigenic state in humans requires further analysis. Although inac- tivating mutations of $P A T C H E D$ can result in medulloblastoma, a tumor of cerebellar granule cells, the spinal cord is not affected in such patients. Nevertheless, Shh causes proliferation in spinal cord precursor cells in vitro (Kalyani et al., 1998) and in vivo (present study). Our results suggest that severe temporal restrictions on cellular competence could limit a putative "tumorigenic window" to only a few days of embryogenesis in the spinal cord. In this regard it is interesting to note that cerebellar granule cells are the latest population of CNS precursors to undergo terminal differentiation. Thus it is possible that the relatively long period of granule cell competence may facilitate stochastic events required for tumorigenic transformation in response to Hedgehog pathway activation in humans and mice.

\section{REFERENCES}

Bellusci S, Furuta Y, Rush MG, Henderon R, Winnier G, Hogan BL (1997) Involvement of sonic hedgehog (Shh) in mouse embryonic lung growth and morphogenesis. Development 124:53-63.

Brand AH, Perrimon N (1993) Targeted gene expression as a means of altering cell fates and generating dominant phenotypes. Development 118:401-415.

Briscoe J, Sussel L, Serup P, Hartigan-O'Connor D, Jessell TM, Rubenstein JL, Ericson J (1999) Homeobox gene Nkx2.2 and specification of neuronal identity by graded Sonic hedgehog signalling. Nature 398:622-627.

Chen H, Lun Y, Ovchinnikov D, Kokubo H, Oberg KC, Pepicelli CV, Gan L, Lee B, Johnson RL (1998) Limb and kidney defects in Lmx1b mutant mice suggest an involvement of LMX1B in human nail patella syndrome. Nat Genet 19:51-55.

Chiang C, Litingtung Y, Lee E, Young KE, Corden JL, Westphal H, Beachy PA (1996) Cyclopia and defective axial patterning in mice lacking sonic hedgehog gene function. Nature 383:407-413.

Dahmane N, Lee J, Robins, Heller P, Ruiz i Altaba A (1997) Activation of the transcription factor Gli1 and the Sonic hedgehog signalling pathway in skin tumours. Nature 389:876-881.

Dale JK, Vesque C, Lints TJ, Sampath TK, Furley A, Dodd J, Placzek M (1997) Cooperation of BMP7 and SHH in the induction of forebrain ventral midline cells by prechordal mesoderm. Cell 90:257-269.

Danielian PS, McMahon AP (1996) Engrailed-1 as a target of the Wnt-1 signalling pathway in vertebrate midbrain development. Nature 383:332-334

Dickinson ME, Krumlauf R, McMahon AP (1994) Evidence for a mitogenic effect of Wnt-1 in the developing mammalian central nervous system. Development 120:1453-1471.

Duprez D, Fournier-Thibault C, LeDourain N (1998) Sonic hedgehog induces proliferation of committed skeletal muscle cells in the chick limb. Development 125:495-505.

Echelard Y, Epstein DJ, St.-Jacques B, Shen L, Mohler J, McMahon JA, McMahon AP (1993) Sonic hedgehog, a member of a family of putative signaling molecules, is implicated in the regulation of CNS polarity. Cell 75:1417-1430.

Echelard Y, Vassileva G, McMahon AP (1994) Cis-acting regulatory sequences governing Wnt-1 expression in the developing mouse CNS. Development 120:2213-2224.

Epstein DA, Marti E, Scott MP, McMahon AP (1996) Antagonizing cAMP-dependent protein kinase $\mathrm{A}$ in the dorsal CNS activates a conserved sonic hedgehog signaling pathway. Development 122:2885-2894.

Ericson J, Morton S, Kawakami A, Roelink H, Jessell TM (1996) Two critical periods of Sonic Hedgehog signaling required for the specification of motor neuron identity. Cell 87:661-673.

Ericson J, Rashbass P, Schedl A, Brenner-Morton S, Kawakami A, van Heyningen V, Jessell TM, Briscoe J (1997) Pax6 controls progenitor cell identity and neuronal fate in response to graded Shh signaling. Cell 90:169-180.

Fan CM, Tessier-Lavigne M (1994) Patterning of mammalian somites by surface ectoderm and notochord: evidence for sclerotome induction by a hedgehog homolog. Cell 79:1175-1186.

Fedtsova NG, Turner EE (1997) Inhibitory effects of ventral signals on the development of Brn-3.0-expressing neurons in the dorsal spinal cord. Dev Biol 190:18-31.

Forbes AJ, Lin H, Ingham PW, Spradling AC (1996) hedgehog is re- 
quired for the proliferation and specification of ovarian somatic cells prior to egg chamber formation in Drosophila. Development 122:1125-1135.

Gavrieli Y, Sherman Y, Ben-Sasson SA (1992) Identification of programmed cell death in situ via specific labeling of nuclear DNA fragmentation. J Cell Biol 119:493-501.

Goodrich LV, Johnson RL, Milenkovic L, McMahon JA, Scott MP (1996) Conservation of the hedgehog/patched signaling pathway from flies to mice: induction of a mouse patched gene by Hedgehog. Genes Dev 10:301-312.

Goodrich LV, Milenkovic L, Higgins KM, Scott MP (1997) Altered neural cell fates and medulloblastoma in mouse patched mutants. Science 277:1109-1113.

Goulding MD, Chalepakis G, Deutsch U, Erselius JR, Gruss P (1993) Pax-3, a novel murine DNA binding protein expressed during early neurogenesis. EMBO J 10:1135-1147.

Hahn H, Wicking C, Zaphiropoulous PG, Gailani MR, Shanley S, Chidambaram A, Vorechovsky I, Holmberg E, Unden AB, Gillies S, Negus K, Smyth I, Pressman C, Leffell DJ, Gerrard B, Goldstein AM, Dean M, Toftgard R, Chenevix-Trench G, Wainwright B, Bale AE (1996) Mutations of the human homolog of Drosophila patched in the nevoid basal cell carcinoma syndrome. Cell 85:841-851.

Homma S, Yaginuma H, Oppenheim RW (1994) Programmed cell death during the earliest stages of spinal cord development in the chick embryo: a possible means of early phenotypic selection. J Comp Neurol 345:377-395.

Huang Z, Kunes S (1996) Hedgehog, transmitted along retinal axons, triggers neurogenesis in the developing visual centers of the Drosophila brain. Cell 86:411-422.

Hui CC, Slusarski D, Platt KA, Holmgren R, Joyner AL (1994) Expression of three mouse homologs of the Drosophila segment polarity gene cubitus interruptus, Gli, Gli-2, and Gli-3, in ectoderm- and mesodermderived tissues suggests multiple roles during postimplantation development. Dev Biol 162:402-413.

Hynes M, Stone DM, Dowd M, Pitts-Meek S, Goddard A, Gurney A, Rosenthal A (1997) Control of cell pattern in the neural tube by the zinc finger transcription factor and oncogene Gli-1. Neuron 19:15-26.

Ingham PW (1998) Transducing hedgehog: the story so far. EMBO J 17:3505-3511.

Ingham PW, Taylor AM, Nakano Y (1991) Role of the Drosophila patched gene in positional signalling. Nature 353:184-187.

Ishibashi M, Moriyoshi K, Sasai Y, Shiota K, Nakanishi S, Kageyama R (1994) Persistent expression of helix-loop-helix factor HES-1 prevents mammalian neural differentiation in the central nervous system. EMBO J 13:1799-1805.

Ishibashi M, Ang SL, Shiota K, Nakanishi S, Kageyama R, Guillemot F (1995) Targeted disruption of mammalian hairy and Enhancer of split homolog-1 (HES-1) leads to up-regulation of neural helix-loop-helix factors, premature neurogenesis, and severe neural tube defects. Genes Dev 9:3136-3148.

Jensen AM, Wallace VA (1997) Expression of sonic hedgehog and its putative role as a precursor cell mitogen in the developing mouse retina. Development 124:363-371.

Jessell TM, Lumsden A (1997) Inductive signals and the assignment of cell fate in the spinal cord and hindbrain. In: Molecular and cellular approaches to neural development (Cowan WM, Jessell TM, Zipursky SL, eds), pp 290-305. New York: Oxford UP.

Johnson RL, Rothman AL, Xie J, Goodrich LV, Bare JW, Bonifas JM, Quinn AG, Myers RM, Cox DR, Epstein Jr EH, Scott MP (1996) Human homolog of patched, a candidate gene for the basal cell nevus syndrome. Science 272:1668-1671.

Kalyani AJ, Piper D, Mujtaba T, Lucero MT, Rao MS (1998) Spinal cord neuronal precursors generate multiple neuronal phenotypes in culture. J Neurosci 18:7856-7868.

Lance-Jones C (1982) Motoneuron cell death in the developing lumbar spinal cord of the mouse. Dev Brain Res 4:473-479.

Lee KJ, Mendelsohn M, Jessell TM (1998) Neuronal patterning by BMPs: a requirement for GDF7 in the generation of a discrete class of commissural interneurons in the mouse spinal cord. Genes Dev 12:3394-3407.

Liem Jr KF, Tremml G, Jessell TM (1997) A role for the roof plate and its resident $\mathrm{TGF} \beta$-related proteins in neuronal patterning in the dorsal spinal cord. Cell 91:127-138.

Lyons KM, Hogan BL, Robertson EJ (1995) Colocalization of BMP 7 and BMP 2 RNAs suggests that these factors cooperatively mediate tissue interactions during murine development. Mech Dev 50:71-83.

Ma Q, Sommer L, Cserjesi P, Anderson DJ (1997) Mash1 and neurogenin 1 expression patterns define complementary domains of neuroepithelium in the developing CNS and are correlated with regions expressing notch ligands. J Neurosci 17:3644-3652.

Marigo V, Davey RA, Zuo Y, Cunningham JM, Tabin CJ (1996) Biochemical evidence that patched is the Hedgehog receptor. Nature 384:176-179.

Marti E, Takada R, Bumcrot DA, Sasaki H, McMahon AP (1995a) Distribution of Sonic hedgehog peptides in the developing chick and mouse embryo. Development 121:2537-2547.

Marti E, Bumcrot DA, Takada R, McMahon AP (1995b) Requirement of $19 \mathrm{~K}$ form of Sonic hedgehog for induction of distinct ventral cell types in CNS explants. Nature 375:322-325.

Monsoro-Burq AH, Bontoux M, Vincent C, Le Douarin NM (1995) The developmental relationships of the neural tube and the notochord: short and long term effects of the notochord on the dorsal spinal cord. Mech Dev 53:157-170.

Orentas DM, Hayes JE, Dyer KL, Miller RH (1999) Sonic hedgehog signaling is required during the appearance of spinal cord oligodendrocyte precursors. Development 126:2419-2429.

Ornitz DM, Moreadith RW, Leder P (1991) Binary system for regulating transgene expression in mice: targeting int-2 gene expression with yeast GAL4/UAS control elements. Proc Natl Acad Sci USA 88:698-702.

Oro AE, Higgins KM, Hu Z, Bonifas JM, Epstein Jr EH, Scott MP (1997) Basal cell carcinomas in mice overexpressing sonic hedgehog. Science 276:817-821.

Placzek M, Jessell TM, Dodd J (1993) Induction of floor plate differentiation by contact-dependent, homeogenetic signals. Development 117:205-218.

Poncet C, Soula C, Trousse F, Kan P, Hirsinger E, Pourquie O, Duprat AM, Cochard P (1996) Induction of oligodendrocyte progenitors in the trunk neural tube by ventralizing signals: effects of notochord and floor plate grafts, and of sonic hedgehog. Mech Dev 60:13-32.

Porter JA, Ekker SC, Park WJ, von Kessler DP, Young KE, Chen CH, Ma Y, Woods AS, Cotter RJ, Koonin EV, Beachy PA (1996) Hedgehog patterning activity: role of a lipophilic modification mediated by the carboxy-terminal autoprocessing domain. Cell 86:21-34.

Price M, Lazzaro D, Pohl T, Mattei MG, Ruther U, Olivo JC, Duboule D, Di Lauro R (1992) Regional expression of the homeobox gene Nkx-2.2 in the developing mammalian forebrain. Neuron 8:241-255.

Pringle NP, Richardson WD (1993) A singularity of PDGF alphareceptor expression in the dorsoventral axis of the neural tube may define the origin of the oligodendrocyte lineage. Development 117:525-533.

Pringle NP, Yu WP, Guthrie S, Roelink H, Lumsden A, Peterson AC, Richardson WD (1996) Determination of neuroepithelial cell fate: induction of the oligodendrocyte lineage by ventral midline cells and sonic hedgehog. Dev Biol 177:30-42.

Raffel C, Jenkins RB, Frederick L, Hebrink D, Alderete B, Fults DW, James CD (1997) Sporadic medulloblastomas contain PTCH mutations. Cancer Res 57:842-845.

Roelink H, Augsburger A, Heemskerk J, Korzh V, Norlin S, Ruiz i Altaba A, Tanabe Y, Placzek M, Edlund T, Jessell TM (1994) Floor plate and motor neuron induction by vhh-1, a vertebrate homolog of hedgehog expressed by the notochord. Cell 76:761-775.

Roelink H, Porter JA, Chiang C, Tanabe Y, Chang DT, Beachy PA, Jessell TM (1995) Floor plate and motor neuron induction by different concentrations of the amino-terminal cleavage product of sonic hedgehog autoproteolysis. Cell 81:445-455.

Ruppert JM, Vogelstein B, Kinzler KW (1991) The zinc finger protein GLI transforms primary cells in cooperation with adenovirus E1A. Mol Cell Biol 11:1724-1728.

Sasai Y, Kageyama R, Tagawa Y, Shigemoto R, Nakanishi S (1992) Two mammalian helix-loop-helix factors structurally related to Drosophila hairy and Enhancer of split. Genes Dev 6:2620-2634.

Sasaki H, Hogan BL (1993) Differential expression of multiple fork head related genes during gastrulation and axial pattern formation in the mouse embryo. Development 118:47-59.

Stone DM, Hynes M, Armanini M, Swanson TA, Gu Q, Johnson RL, Scott MP, Pennica D, Goddard A, Phillips H, Noll M, Hooper JE, de Sauvage F, Rosenthal A (1996) The tumour-suppressor gene patched encodes a candidate receptor for Sonic hedgehog. Nature 384:129-134.

Storm EE, Huynh TV, Copeland NG, Jenkins NA, Kingsley DM, Lee SJ 
(1994) Limb alterations in brachypodism mice due to mutations in a new member of the TGF beta-superfamily. Nature 368:639-643.

Sun T, Pringle NP, Hardy AP, Richardson WD, Smith HK (1998) Pax6 influences the time and site of origin of glial precursors in the ventral neural tube. Mol Cell Neurosci 12:228-239.

Tabin CJ, McMahon AP (1997) Recent advances in hedgehog signaling. Trends Cell Biol 7:442-446.

Tanabe Y, Jessell TM (1996) Diversity and pattern in the developing spinal cord. Science 274:1115-1123.

Tanabe Y, William C, Jessell TM (1998) Specification of motor neuron identity by the MNR2 homeodomain protein. Cell 95:67-80.

Theil T, Zechner U, Klett C, Adolph S, Moroy T (1994) Chromosomal localization and sequences of the murine Brn-3 family of developmental control genes. Cytogenet Cell Genet 66:267-271.

van Straaten HWM, Hekking JWM, Beursgens JPWM, TerwindtRouwenhorst E, Drukker J (1989) Effect of the notochord on proliferation and differentiation in the neural tube of the chick embryo. Development 107:793-803.

Vorechovsky I, Tingby O, Hartman M, Stromberg B, Nister M, Collins VP, Toftgard R (1997) Somatic mutations in the human homologue of
Drosophila patched in primative neuroctodermal tumors. Oncogene 15:361-366.

Wallin J, Wilting J, Koseki H, Fritsch R, Christ B, Balling R (1994) The role of Pax-1 in axial skeleton development. Development 120:1109-1121.

Walther C, Gruss P (1991) Pax-6, a murine paired box gene, is expressed in the developing CNS. Development 113:1435-1449.

Wang Y, DeMayo FJ, Tsai SY, O'Malley BW (1997) Ligand-inducible and liver-specific target gene expression in transgenic mice. Nat Biotech 15:239-243.

Wechsler-Reya RJ, Scott MP (1999) Control of neuronal precursor proliferation in the cerebellum by Sonic Hedgehog. Neuron 22:103-114.

Whiting J, Marshall H, Cook M, Krumlauf R, Rigby PWJ, Stott D, Allermann RK (1991) Multiple spatially specific enhancers are required to reconstruct the pattern of Hox-2.6 gene expression. Genes Dev 5:2048-2059.

Wilkinson DG (1992) Whole mount in situ hybridization. In: In situ hybridization: a practical approach (Wilkinson DG, ed), pp 75-83. Oxford: IRL. 